\title{
Comparison of arrogance in Shahnameh and Bahmannameh based on the ancient story of Bahmannameh
}

\section{Comparación de la arrogancia en Shahnameh y Bahmannameh basada en la antigua historia de Bahmannameh}

\section{Zohreh Amiri}

PhD student in Persian Language and Literature, Islamic Azad University, Mashhad Branch, Iran

\section{Reza Ashrafzadeh}

Professor of Persian Language and Literature, Islamic Azad University, Mashhad Branch, Iran

\section{Mohammad Shah Badiezadeh}

Professor of Persian Language and Literature, Islamic Azad University, Mashhad Branch, Iran

*Correspondence

Email: Zohreamirima@yahoo.com
Cite as:

Amiri, Z., Ashrafzadeh, R., \& Shah Badiezadeh, M. (2021). Comparison of arrogance in Shahnameh and Bahmannameh based on the ancient story of Bahmannameh. Propósitos y Representaciones, 9(SPE3), e1092. Doi: http://dx.doi.org/10.20511/pyr2021.v9nSPE3.1092 


\section{Summary}

One of the most important aspects of the struggle of warriors and warriors in epic works is the arrogance that is called by the comrades before the start of the hand-to-hand battle. It is accompanied by pride in ancestry, race, and ridicule. Ferdowsi's Shahnameh is full of unique arrogance that has given its poet a special place with special and various skills, so that these styles have been welcomed and imitated by poets after Ferdowsi. In the meantime, Bahmannameh written by Iranshah Ibn Abi Al-Khair has a special place. In this work, the heroes have boasted in different ways before the battle. This study has selected the examples of boasting of the warriors in the two mentioned works and comparing them to examine their advantages and disadvantages in relation to each other.

Keywords: Shahnameh, Bahmannameh, Arrogance, Humiliation, Pride

\section{Resumen}

Uno de los aspectos más importantes de la lucha de guerreros y guerreros en obras épicas es la soberbia que llaman los compañeros antes del inicio del combate cuerpo a cuerpo. Va acompañado de orgullo por la ascendencia, la raza y el ridículo. El Shahnameh de Ferdowsi está lleno de una arrogancia única que le ha dado a su poeta un lugar especial con habilidades especiales y variadas, por lo que estos estilos han sido acogidos e imitados por poetas posteriores a Ferdowsi. Mientras tanto, Bahmannameh escrito por Iranshah Ibn Abi Al-Khair tiene un lugar especial. En este trabajo, los héroes se han jactado de diferentes formas antes de la batalla. Este estudio ha seleccionado los ejemplos de jactancia de los guerreros en las dos obras mencionadas y comparándolos para examinar sus ventajas y desventajas entre sí.

Palabras clave: Shahnameh, Bahmannameh, Arrogancia, Humillación, Orgullo

\section{Introduction}

The land of Iran, with its civilization of several thousand years and its ups and downs, is the home of epic men and women who have preserved this land and its moral virtues with their courage, bravery and religiosity. Epic works have been created to preserve these values.

The mythology of ancient Iran, both those recorded during the Islamic era and those that have found their way into Islamic and prose works, is strongly influenced by the epic spirit and atmosphere that was appropriate for the time. War is always a major concern for the people. Ancient Iran was and has influenced a large part of their lives, and in this regard, an important part of the cultural and historical body of the ancient period has been established, from which the religious-literary works of that period are reflected. Naturally, bragging in these wars is an important expression of the pride of Iranians. One of the most important ancient fiction collections is Khotai Namag, which appeared in the late Sassanid era, and since the basis of the stories of Shahnameh is based on its narratives, it is obvious that arrogance is one of the most important topics in the epic works of the place. It has found itself in it. The importance of epic narratives has been such that in a religious work such as Avesta, there are signs of describing heroic deeds and boasting about the language of heroes. Persian literature in the fourth and fifth centuries AH is of special importance in terms of epic writing. These two centuries are the peak of epic writing in Persian literature. Most of the important Persian works such as Shahnameh, Bahmannameh and Garshasbnameh have been arranged in these two centuries. What is remarkable about these epic poems is the arrogance of the heroes in the battlefields. In addition, it is necessary to examine the different functions and manifestations of these braggarts. 


\section{Statement of the problem:}

By composing Shahnameh, Ferdowsi has reached the peak of epic poetry in Persian literature. His method of composing epic is irreplaceable and arrogance is certainly one of the most important and epic parts of Shahnameh. And they have used his techniques to see how successful Iran Shah has been in composing epics, especially Rajaz, compared to Ferdowsi. Importance and necessity of research:

This is because the concept of arrogance and conceit is seen in today's conversations and conflicts, and even politicians are commenting on this concept in their speeches. It is necessary to raise this issue in order to raise the awareness of the people and society so that the teachings of Shahnameh and Bahmannameh in this regard will pave the way for today's generation. On the other hand, recognizing the arrogance and its functionality enables us to understand their differences

Key research questions:

In the field of arrogance and arrogance, in the two mentioned works (Shahnameh and Bahmannameh), there are questions that we have answered in this research.

- Do arrogance have different approaches and functions in two works?

- Can the motivation of the heroes be the same in arrogance or are they different?

- In terms of tone and language, the effect of arrogance in which work is preferable to another?

- Have women boasted in these two works? With what purpose and approach?

\section{Research background:}

In the field of comparing arrogance and arrogance in Shahnameh and Bahmannameh, no independent study has been done so far. However, articles have been written in the field of comparing arrogance, epic works such as the function of arrogance and arrogance in Shahnameh and Garshasbnameh written by Katayoun Moradi or arrogance in Shahnameh written by Gholam Ali Fallah.

However, it can be said that this is the first research done in comparison with the two works. Research sections:

Part 1: Familiarity with the definitions of epic and arrogance

Part 2: Introducing Bahmannameh

Part 3: Men's boasting in Shahnameh and Bahmannameh

Section 4: Women's arrogance in Shahnameh and Bahmannameh

\section{The first part}

\section{Familiarity with the definitions of epic and arrogance}

Epic in the literal sense; Courage, courage, intensity and difficulty in work, as well as courage and hardship have been mentioned (Dehkhoda, below the epic)

The equivalent used by critics in recent times is epic, which is a The term is Greek. But epics have many definitions in terms of terminology, some of which we will mention.

"Epic is one of the literary genres known by Aristotle as the second type of literature after tragedy, and it is a long, narrative poem that usually focuses on the extraordinary biographies and heroic deeds of the hero, and with the important events that are unusual. "It's often about the fate of a tribe or a nation, and sometimes it's about the human race in general." (Mirsadeghi, 1373: 95) 
Another source described the epic as "a kind of descriptive poem based on descriptions of heroic deeds, masculinity, honor, and ethnic or individual greatness that encompasses various aspects of their lives." (Safa, 1984: 3).

Based on the fact that the epic is a long and fictional poem, and the description of the heroism and honors of a people, there are some features for it, which are listed as follows:

1- The main hero of the epic is usually an ideal hero or human being who is prominent in terms of physical and spiritual strength.

2. The existence of superior beings and metaphysical forces in epics and gods, especially in Greek mythology.

3. Animals that play an important role in the epic and are often not ordinary. For example, Achilles' horse, which has the power of prophecy, or Rakhsh Rostam, which in most cases is given to Rostam.

4. Strange plants with magical properties are present in the epic, such as the humus plant discovered by Fereydoun and it is a kind of antidote or the Siavash plant that grows from the ground after Siavash's blood is shed.

5- Usually, a beautiful goddess or lady is placed in the way of the epic hero and falls in love with him, and in most cases, he provides troubles for the hero. Like Tahmineh, who is on the way to Rostam and provides the grounds for the murder of Rostam.

6- Because the epic was composed to be read aloud, its language was glorious and glorious.

7- Describing the scenes of hand-to-hand combat that begins with verbal warfare and arrogance. Since the last two features of the epic are directly related to this research, it is necessary to articulate these two features in detail.

The questions and answers of the heroes before the start of the battle are completely different from the common language, and the language is quite detailed and glorious, along with a certain kind of song and special weight.

"The arrogance of the indisputable etiquette of the arrogant war and the two fighters were forced to deal with it before the battle. In fact, boasting is part of the warriors' tactics to break the enemy's morale. From a psychological point of view, in arrogance, on the one hand, we can consider the speaker's pride and his confidence in defeating the opponent, and on the other hand, the speaker's hidden apprehension and fear of failing beyond his words can be taken as a cover to hide this fear. Knew. (Fallah, 2006: 110)

\section{Pride is seen in all the epics of the world}

The origin of the word is Arabic, and its literal meaning in Arabic is "the pain that strikes the camel's incapacity, as well as the anxious meanings of the camel's foot, the sting of eating, and the breach of promise" (Ibn Manzur, 1968: Rajz).

In addition, it means the movement of camels. Furthermore, arrogance means the trembling that a camel finds in its knees or arms and legs when it is lifted, and that vibration, and the female is called arrogance, that is, a camel whose legs are weak and when it is lifted from where it is. he is sleeping. That is why Rajz has been called Rajz in his poetry because of the closeness of its components and its few letters (ibid.).

But Rajz in Persian cultures also has the following meanings:

Poetry that is sung by each of the parties during the war in praise of their people and honors is one of the seas of poetry that is obtained by repeating it three or four times (Moin, below Rajz). And elsewhere it says: 
Pride has been used in Persian to mean boasting and expressing masculinity and self-esteem, boasting pride, boasting and stubbornness, and combinations such as bragging, bragging, etc. have become popular in Persian (Dehkhoda, Dictionary). ) And in literary terms, a poem is said in which the fighters, in the position of pride and arrogance, speak in the expression of their masculinity and that of their family, especially on the battlefield (Dehkhoda, Nafisi, below Rajz).

What has been learned from the definitions of Arabic and Persian dictionaries about arrogance is that arrogance is a poem that is uttered on the battlefield to glorify and humiliate the enemy, and apparently, as arrogant, he goes to the enemy and stands and reads arrogantly. And it moves again. This type of poetry reading, which is like the movement of a sick camel, has been called arrogant, so the visual aspect of arrogance is also the criterion in this naming. In short, "arrogance is one of the special speeches of epic literature, and in general it is the arrogance of the heroes and the expression of their deeds and honors. It is mostly used during the war, but in other situations as well." We eat "(Sarami, 1989: 300).

So define the honors that are outside the battlefield or the usual bragging outside of that definition.

With this description, Rajz is a kind of face-to-face conversation on the battlefield that takes place between man and man or human and extraordinary and mythical animals, and is often expressed in the form of questions and answers, and because Rajz is a kind of conversation. There are three main elements in it.

\section{1- Arrogant reader (messenger)}

2- Rajz listener or listeners (recipient message)

3- Arrogance (message)

In addition, sub-elements such as time, place, tools and position are added to these three elements. And the important point about the time and place of arrogance in epic works is that the hero or hero tries to express arrogance in the shortest terms and in the shortest time in terms of lack of time, in order to be psychologically superior to the opponent as soon as possible. Overcomes and disturbs the mental body by hitting it, so the arrogant have the speed of expression and the shortness of time.

Regarding time and place in arrogance, it can be said: "Time and place are general and vague, but specific and limited, and another important point is that the expression of arrogance in the general context of the story is important in terms of order and sequence, that is, although time It doesn't matter and it's general, but Rajz's time order and sequence are important. Rajaz Khan must first introduce himself in terms of time precedence or introduce himself to the opponent with a short Rajazi in response to the question of his name and lineage, and then to the enemy's honors and humiliation. Pay. (Ibid: 302).

\section{Part 2 \\ Introducing Bahmannameh}

Bahmannameh is one of the national epic poems composed by Iranshah Ibn Abi Al-Khair. This poem was composed in the late fifth or early sixth century AH. There is no accurate information about the author of the poem. It can also be said that he was a follower of Islam and most likely a Shiite, according to the introduction of the book and the discussions he had during the book. It is necessary to mention that the author of the Bahman Assembly has attributed Bahman to a person named Jamali Mehr Yajardi, but considering that there is no mention of Jamali Mehr Yajardi anywhere else in Persian memoirs, the words of the owner of the assembly are not reliable. (Afifi, 1991: 12) 
In the preface of Bahman, the poet praises Sultan Mohammad, the son of the Seljuk king, in his verses, and speaks of the turmoil that has arisen after the death of Malikshah and lasted for ten years, as well as the bravery of Muhammad, who was able to change the situation. Calm down and calm down the insurgents, and the same bravery and heroism of Sultan Mohammad reminded the story of Bahman, the son of Esfandiar, in the memory of Iranshah, and wished to write this story from the ancient saying of the name of God Almighty (Sultan Mohammad):

Zekdar of this infamous prince

I remembered Bahman Esfandiar

What did Faramarz Rostam do with him?

Count on him for a year

I longed for this story

To the poem of the logo from the ancient saying

(Ibid: 14).

According to Dr. Zabihullah Safa, the poet has revised his collection several times because in some versions the book has been dedicated to Mahmoud bin Malekshah, but in any case in the original version by Master Rahim. Afifi has been published. The book has been dedicated to Mohammad. According to this version, the number of verses is 10,400 verses. This work has been written in the symmetrical weight of Muthamman Maqzaf or Maqsoor, and its subject is the life of Bahman, the son of Esfandiar, and the way he came to power and his battles with the Zal family. In general, there are four sections, which we briefly introduce.

1- In the first part of the story, Dehghan Mobdenjad starts the story and gives a brief overview of Kiomars to Kavous, then Kavous's disobedience to the cosmos of Khadio and his asceticism, and then Siavash's blood and Kaykhosrow's coming to Iran and handing over the kingdom to Sohrab and the kingdom. Goshtasb and the killing of Esfandiar by Rostam and the arrival of Bahman in the kingdom have been discussed. In the continuation of this section, Bahman's accession to the throne and his marriage to Katayoun, the daughter of the king of Kashmir, and then his marriage to Homay, the daughter of the daughter of the king of Egypt, are discussed.

2- The second part begins with the decoration of the IRGC by Bahman to fight Faramarz and Zal. The battalion and the warriors each gather with a special flag and a war arrangement is arranged, and Bahman is placed in the stem of the army, and the troops take the road to Sistan. In these battles, Bahman is defeated three times, and finally the fourth battle begins after several years, and Jamasb Farzaneh gives the good news to Bahman that victory will be with him in this battle, and this is what will happen, and many Sistan warriors have been killed. Faramarz is arrested and hanged, and Zal, trapped in an iron cage, is imprisoned on the back of a prisoner, and Sistan is razed to the ground, Zal's treasures are looted, and other members of his family flee to Kashmir.

3- In the third part of the story of the escape of Rostam's daughters and his people to Kashmir and their pursuit by Bahman, as well as Bahman's visit to the Cave of Heroes and the renovation of Sistan, Mrs. Goshasb and Zarbano, Rostam's daughters, and two of them go to Nakhreh and Marzban will go to Kashmir after the war and ask the king of Tire for safety, and the king of Tire will welcome them because of his hatred of Bahman. Bahman asks the king of Tire to send Rostam's daughters to him, but the king does not accept Tire, and as a result, a fierce battle ensues between the two. And in this war, Takhareh and Marzban are captured and imprisoned along with Zal. Following the story, Rostam's daughters escape to the court of Shah Tibal, and after a chase and successive battles, Rostam's daughters are finally arrested and imprisoned alongside Zal.

4- In the fourth part, there is more talk about Barzin Azar and his fight with Bahman, which eventually leads to peace and reconciliation, and there is talk of Bahman coming back from India and leaving Zal and Rostam's daughters and Faramarz's son's revenge on Bahman. And finally, the story ends with the swallowing of the avalanche by the dragon. 
Differences between Ferdowsi's report on Bahman's malice and Iran Shah's report:

There are differences in both the way the story is told and the way it is narrated. "Bahman's name is first seen in the Shahnameh when he was a teenager. He went to Rostam as a prophet on behalf of his father Esfandiar and conveyed his father's message that Rostam surrendered and informed him, then witnessed and watched the scenes of conversation and battle between Esfandiar and Rostam. When he dies, Esfandiar asks Rostam to take care of Bahman's training. In a letter to Goshtasb, Rostam describes the battle and the death of Esfandiar. Goshtasb also wrote a letter He writes in honor of Rostam and asks him to send Bahman to him. Rostam does the same "(Afifi, 1991: 73)

After this, the Shahnameh talks about the conspiracy of Sheghad and the death of Rostam. After the death of Goshtasb Bahman, he sits on the throne of Iran and goes to Sistan to seek revenge on his father and brothers in order to take revenge on $\mathrm{Zal}$ and Faramarz. He goes and apologizes, but Bahman refuses and arrests him. Faramarz, Rostam's son, provides an army and comes to Sistan to fight Bahman. A fierce battle ensues between them for three days and nights. On the fourth day, a strong wind blows towards Faramarz and his troops, and the heroes of his army flee, and Faramarz $\mathrm{He}$ is forced to continue the fight against Bahman with a small army, the Bahman Battalion intervenes and Ardeshir finally arrests him. And Faramarz will be hanged by Bahman's order. Finally, he released Zal from prison and returned to the capital.

The whole story is told by Ferdowsi in 147 verses, and it is inferred from the examination and implementation of Ferdowsi's report with Iranshah that the source of their poets was not the same.

"In Shahnameh, the death of Rostam is mentioned before the arrival of Bahman in the kingdom, but in Bahman, the letter of Rostam's death is mentioned during the reign of Bahman. In Bahman, the conflict between Bahman and the Zal family lasts 40 years, while in the Shahnameh it lasts three days. "In the Shahnameh, the names of the heroic heroes who performed during the reign of Bahman are not seen, while Bahman's letter of honor and importance of each of the fighters is clear." (Ibid: 75).

Ferdowsi's report on Bahman's malice is also different from Iran's Shah's report. According to Ferdowsi Zal's report in the Bahman response, Esfandiar's death is related to his fate. And he asks him to forget the past, but in the report of Iranshah Zal, after writing his letter, he prepares for battle and when the Bahman troops attack Zabul, he stands in front of them as a man and crushes them. And finally he is captured after three wars.

And the next thing is that Ferdowsi did not say anything about the daughters of Rostam and their bravery and struggle, while one part of the four parts of Bahmannameh was dedicated to the battle between the two and Bahman, which was mostly mentioned.

\section{Iranshah Storytelling Method}

Despite all the above, Iranshah's storytelling style encourages the reader to read the rest of the story. This work is of special importance among our past fictional works, in addition to its importance for its epic structure, in terms of the sequence of mythical events. All the events and scenes of the battle are told in an interesting and eloquent way. We should also mention the truthfulness of the poem, although it is not usually possible to expect the truthfulness of the story due to the main feature of the stories, namely the deviation of habit and generalism, as far as the poet's knowledge and knowledge of his time allowed. It is possible to connect extraordinary events and illusions with reality and bring the story closer to human belief while having imaginary and mythical elements. In this regard, it can be said that Bahmannameh is 
related to Shahnameh (of course, in its mythological and heroic part) from The element of more realism has benefited. (Jafari, 2009: 200).

In addition, the poet has acted in a creative way in his characterization and has created an innovative way of arranging the dialogue between the heroes, which we will talk about in the next lines.

\section{Part 3}

Men's pride in Shahnameh and Bahmannameh

1- Pride of lineage:

What is certain is that the warriors and warriors are proud of their various destinations, and almost the entire team has destined for victory. One of the most important and recurring themes in arrogance is reliance on race and gem, and opponents when confronted with the races of their race and lineage try to weaken the opponent psychologically and ridicule his lineage. In Bahmannameh, before the confrontation between Bahman and Lula, several examples of arrogance take place between the heroes of the two corps.

In the beginning, Bahman sends Naeem to the battlefield. Naeem, who is a greyhound, begins his arrogance as follows:

Badish told them to be rebellious

I will show myself

I am also the name of the brave Naeem

In the forest, there is the fear of milk

Throughout my work day command

Necklace riders six thousand

The same goes for Shah Tazian himself

It's time to dump her and move on

One man will not fight the test

To walk with me in this battle

Death and gem deserve me

My speech is contagious

(Bahmannameh, 1991: 145).

While Naeem is proud of his lineage, he demands an opponent from the opposite army who is the owner of the lineage, name and badge and deserves to fight with him. The battle with Naeem goes to the field:

He said to the brave fisherman

You didn't leave Farah Shir in the woods

Come on, said the famous Kai

Right now, it's riding an Ivor

So the horse came out

That's what Kai Dave Chehr said

Say the name of the race you have

That the name and race do not belong to the universe

He said, "Your death is my name."

The destruction of your corps is mine 
When the fire went, he attacked one of them

It turned out to be a dark circle

(Ibid: 145).

In Ferdowsi's Shahnameh, where Siavash's son, the Iranian Corps, under the command of Gio Pahlavan Irani and Rostam's son-in-law, travels to Turan after Foroud's death. And the race begins:

Gio went to him

How many of you are with him

Ask about the confusion and its name

That's what Kai said. Aggressive

That's why people came to war

We came to the whale's mouth

He replied that he was famous

See now the infantry battle

My name is Giti Taj

Rejoice with the people

I got my race from Iran

Get rid of the back of the lions

Now my border guards are flat and sometimes

Negin the elders and the groom of the king

(Shahnameh, 1374: 333)

Tragedy against Gio, who is a well-known hero of tribal origin, is forced to marry Afrasiab's son-in-law and consider himself an Iranian. A common feature of Naeem and Tajav's arrogance is that when they stand in front of the Iranian heroes, they both see themselves as inferior to the Iranian heroes in terms of race and origin, and as a result they are forced to connect themselves somewhere. Naeem introduces himself as a relative of the Tazian king.

The same goes for Shah Tazian himself

It's time to dump her and move on

(Bahmannameh, 1991: 145).

In Tajavo's confrontation with Gio, Pahlavan Turani, in addition to claiming that his origin and race are rooted in Iran, introduces himself as Afrasiab's son-in-law.

I got my race from Iran

Rotten and from behind the lions

Now my border guards are flat and sometimes

Negin the elders and the groom of the king

(Ibid: 333 )

But Gio gets upset when he hears this. Because he does not consider Iranians as patriots, he is humiliated by his anger over this statement and the IRGC.

He said at first, "Don't say that."

To darken Zayn's reputation 
He sat down with Turan from Iran

But if he ate it, it would be blood

If the border guard and the king's son-in-law

Why don't you have more saddles?

(Same)

Here, pride in nationality and patriotism is an honor that the arrogant reader has shown.

\section{Humiliating}

Another function of arrogance is to humiliate and ridicule the opponent. Scholars have considered mockery to be a matter of "humiliation" and synonymous with ridicule and humiliation, and have said: Be" (Mostafavi, 1385: 256).

This kind of arrogant function, which is accompanied by concepts such as corrupting, encroaching, humiliation, weakening and humiliating the enemy, has also been interpreted as rhetoric.

"The word gouache in cultures means sarcasm, blame, and gossip means condemnation and slander. Apparently, the word is a combination of the prefix $g$ and the word word. "G" is based on some words and has changed their meaning to the original meaning. This is the kind of "suspicion" that arises from $\mathrm{G}$ plus our man = to think and to go, which is derived from G plus = and is quite the opposite of the meaning of happy, that is, well arose and evokes pleasantness "(Sarami, 2004: 270).

And since the word and mockery in their nature is accompanied by humiliation and insult, it destroys the enemy's fighting spirit and in the battlefields of the warriors, while enumerating their honors and their tribe, they mock the lineage and race or the land of the opposing warriors. To achieve his main goal, which is to weaken his morale.

In Ferdowsi's Shahnameh, there are many references to this subject, and now we will examine some examples of them, and then we will bring examples of Bahmannameh for comparison and comparison.

1- Rostam and Esfandiar often make fun of each other in battle with each other. At the beginning of Rostam's confrontation, after listing his services to Iran and the kings of Iran and Esfandiar's ancestors, he addressed him as follows:

That I was in the world of Kamran

I had expensive swords and maces

I told him this until you all knew

You are a king and their neck is like a herd

You have not arrived in time

If a few buffers

You see your body in the world

Not if it's a secret

(Shahnameh, 1374: 731)

Rostam points to Esfandiar's youth and inexperience and self-esteem in order to humiliate him. Esfandiar, on the other hand, responds after listing his racial honors:

You are the one before my ancestors

My awake and pure elders 
You were a worshiper with Nia

Let's not talk about Kimia's words

You have found the greatness of my kings

You are in a sharp bondage

(Same).

Esfandiar also warns Rustam that if he has found a name and address, he has been in the shadow of the support of the Goshtasb family.

Elsewhere in the same war letter, after Rostam and Rakhsh are wounded by Esfandiar's bullet, Esfandiar humiliates and mocks Rostam as follows:

Laugh because you saw Esfandiar

At first, Kai said, Rostam is famous

Why was that drunken cell force lost?

Zepikan Why did you fight a war cell?

Why did you run upstairs?

You sang the song of the lion

Why did the fox become a fox?

Such a short hand was cut short

(Ibid: 743)

Esfandiar's use of the word fox for Rostam is one of the highlights of this humiliation. Because everywhere in the Shahnameh he is referred to as a lion, and few people have had the courage to call Rustam a fox, the story does not end here, and even after Rustam seeks Simorgh and Zal. $\mathrm{He}$ recovers again and comes to the field again. Esfandiar makes fun of him in his arrogance:

You roared because you gave in to Rustam

May your name disappear from the world

You forgot about the dog

Perfection and arrogant man

Zenirang Zali is right

Otherwise, your foot will be buried

Knock on the saddle today

Kazin will not see you alive again

(Ibid: 749)

Esfandiar's use of the word "Segzi" in Rostam is a kind of humiliation of his name and lineage. While humiliating Rostam, these humiliations also weaken his morale, but Rostam, who is a morally oriented hero, tries to advise and To dissuade Esfandiar's advice, but since Esfandiar's arrogance and pride are heavier than Rostam's advice, Rostam will inevitably kill him with his arrow and respond to his humiliations as follows:

This is what Rostam told Esfandiar

That you brought that seed of seed

You are the one who said that you are my body

I will raise the heavens above the earth

I have eight arrows from your thumb

I ate, I didn't complain about the name and the shame 
Return to a shooting range

Don't get me wrong

Get your head in the ground now

Burn your mother's kind heart

(Ibid: 750).

In all the answers that Rostam gives to Esfandiar's arrogance, his irrationality rebukes him and tries to keep Esfandiar by keeping his composure, calmly and sometimes even with a laugh of self-confidence and meaning, and sometimes by moving his head. Bring him to himself and warn him against this indecent act.

Rostam and Ashkbos: It is safe to say that one of the most beautiful examples of arrogance with the motive of humiliation and retaliation in the story of Kamus Keshani has occurred between Rostam and Ashkbus. Depicted. After Rostam became angry with Rockham because of Roham's escape, he handed over the IRGC to Toos and did not enter the square on foot.

Going, Ashkbus tells him intently:

He said with a smile, "What's your name?"

The headless body that will cry

(Ibid: 384).

The use of the adjective "smiling" and the expression of speech in the form of a question and, more importantly, the ignorance of the mystics in its negative meaning by Ashkebus, has made the word more and more the color of darkness and ridicule, and Ashkbos tried to pretend that he did not know Rustam. He is humiliated by Rostam, and Rostam replies sarcastically:

The slanderer replied that the name

What do you ask, so you don't see it in your mouth

My mother called me your death

My time has left you

(Ibid: 384).

In the following, Ashkbus mocks Rostam's being without a horse:

Keshani initially said it was barren

To kill the head at once

(Same).

Rostam, without harming his heroic spirit, responds to Ashkebos in order to weaken the opponent's morale, calmly and calmly:

You didn't see a foot that brought war

He brought them under the rock

Milk, whales and leopards to your city

All three are on the battlefield

You haven't ridden yet

Learn to walk

He sent me on foot

To close the spa from Ashkbos

Get down like me 
Zedo smiles on the forum

Walk on five hundred horses like you

This day and this campaign tour

(Ibid: 385).

And these arrows and taunts continue to rise, and finally, when the world of archery hits Ashkebus on the chest and throws him on the ground, he continues to boast of ridicule.

Laugh, Rostam sang

Sit in front of the expensive pair

Put your head on the side

It's time to dump her and move on

(Same)

In the story of Rostam and Sohrab, arrogance along with humiliation and ridicule of the opponent can be seen in several places.

When Sohrab attacks the Iranian troops and finds no one to oppose him, he insults Kikavous in an insulting tone and does not even consider the royal name worthy of him.

He said he died with the free king

Because the card did not go to the plain

Why did you name Kavous Ki?

That in war you have neither tau nor pi!

I'll cut your body with this spear

Let the star cry

(Same).

Here, Sohrab's arrogance is the basis of his arrogance, and his purpose in this arrogance is to humiliate the opponent's name and title. Sohrab provides:

Laugh, Sohrab, and tell him to ride

To the wounds of the brave, not the stable

It's like fighting inside

Two riders are the worst

However, the ball was high

The slow old man was Kana

(Same).

Sohrab's laughter and the resemblance of Rakhsh to the donkey, which is of great value to Rostam, are in order to weaken Rostam and Rakhsh's strength and power as much as possible, and also the cana of old age that evokes a kind of insult and ridicule in the audience's mind. This kind of arrogant function can also be seen in Bahmannameh, and in some places, both Iranian and non-Iranian heroes have done this in order to humiliate each other and also to weaken the opponents' morale. We will deal with the mentioned examples from Shahnameh.

In a letter to Bahman, Bahman addresses him as follows:

Letter from Bahman Esfandiar

The father over the father of the king and the prince

To you, servant of the demon Chehr 
That the wheel of your life will be sealed

Your heart is full of pain and your soul is full of fear

Thank you for your kindness

Just like you ate dog milk

You grew up with a baby wolf

I think you are so miserable

That you suffered in this throne

Iran's capital is superior to it

That someone like him ate you

I came to dig to deserve you

Instead of the logo in your work

Find you gem and name

Kara made me do this to disgrace

(Bahmannameh, 1991: 141).

This type of boasting, which is mostly seen in Bahmannameh as a letter and indirect expression of the heroes to each other, is sometimes exaggerated and goes through humiliation and mockery and insults, and sometimes it takes the form of swearing and insults. .

For example, Ardeshir says in a speech to the Arab hero:

At the beginning, Pahlavan said,

I remember such a story

What came back on the fox's milk?

Put your hands under him

There is no place for hands and deceit

I have no war with you today

I will kill you like a dog

Send your head to the rich

(Ibid: 154).

Here, in addition to Ardeshir to an opponent other than Iran He calls himself a fox and a dog and refers to himself as a lion. Indirectly, he accuses him of witchcraft, deception and lying. Iranians are usually attributed to non-Iranians, and it seems that Ibn Abi al-Khair also consciously and consciously incorporated this theme into the arrogance, as can be seen in the following example:

Chou Bahman reads those harsh words

Shake like a tree branch

He ordered the dog to look

like a demon do not seal us

Cho Segalim Kan Bad Bad Nejad

If he wins, he will return 
(Ibid: 481).

But in Bahmannameh, humiliation is sometimes accompanied by respect and comes out of the state of insult and insult:

So the horse came out

That's what Kai Dave Chehrsavar said

Say the name of the race you have

That the name and race do not belong to the universe

He said, "Your death is my name."

The destruction of your corps is mine

(Ibid: 145).

In the continuation of this confrontation, Mahyar destroys Naeem Arab and Mehran enters the field from the Iranian army and Harith from Egypt and Mehran tells Harith:

He told Harith that he was Kane's man

You have achieved such an achievement

Why should I sing with you?

Fill the earth with blood

Tell me what your name is

Kzin then cried for luck

He said at first that the name and $\log 0$

Once called necklaces

We tried to find art

We talked about name and art

What's the matter with you?

Who went astray in the darkness

(Ibid: 147).

\section{Part 4}

\section{Women's Pride in Shahnameh Bahmannameh:}

One of the most important points to consider in epic works is the presence of women. In most of the epic works, the presence of women can be seen and their undeniable role in failures and victories cannot be ignored. Their role is behind the battlefields, and sometimes as conspiracies that have led to conflicts and wars. But the reality is that "even with the preservation of women's identity, women in the epic epic play major roles in guarding the supremacy of the continuation of the chain of heroes, helping and rescuing Yalan from strange political and sometimes love affairs." They are also taught wisdom and wisdom, which may not be less than men's struggles on the battlefield (Siraj, 2013: 3).

For example, Fereydoun's wise mother Frank, with the proper upbringing of her son, was able to overthrow the tyranny of Zahak, or Manizheh's veteran to save Bijan from the well of Afrasiab and the hero of Zali and the heroism of Rudabeh and Tahmineh cannot be ignored. 
In addition to these roles in epic literature, we encounter women who are very different from other female figures. The character and character of these women are warriors and warriors, and they have a very effective presence in the face and character of warrior women. Common to all of them are listed in most epic works, which we refer to as a list.

1- In terms of lineage and family affiliations, they have a close connection with Shahriari and Pahlavani arrows, and most of them are the daughters or sisters of famous heroes and great Shahriars.

2- In terms of clothing and combat clothing and the use of weapons, they are no different from male warriors and warriors. They wear armor and suffocation and wear their hats and carry weapons such as bows and arrows and swords.

3. Most of them are beautiful and have many fans despite the fight

4. In addition to warfare and militancy, they are often wise and prudent, and in difficult times they can make important decisions and sometimes make wise and anti-war speeches.

5- Although these warriors are women and thin, but when they come to the battlefield, they brag about men's feet and shout loudly, and in the words of epic poets, they "wail" so that their voices are sometimes with Rustam. Or weeping lions are compared. (Ibid., 4)

The first woman warrior who has most of the mentioned characteristics and is mentioned in Shahnameh is Gerd Afrid. Gathering is both beautiful and warrior, and one of the darkest Iranian heroes of this woman appears in the story of Rostam and Sohrab in the Shahnameh, but in this small presence, beauty and elegance play a role in the end.

When Sohrab, Rostam's son, marched on Iran in the position of a Sardar Turani. And he is looking for his father. Sohrab reaches the foot of the White Fortress, which is on the other side of the border and on Iranian soil. At the beginning, a hero named Hajir, whose guard is the fortress, fights with Sohrab and is captured. Although Gerdafarid has seen Sohrab's physical strength and fighting ability to save Hajir and defend the fort, Giso hides under his hat and enters the field in the presence of a male hero and begins to boast and seek help:

Wear war hats

There was no room for delay

He hid his hair under the armor

The knot is tied on the Roman terrace

He descended from the fort to his actions

Lowering the windshield below

He came to the IRGC and turned around

Cho rosy roaring one willow

Who is the battalion and who is the ruler?

Who is the helper of war fighters?

That Berman passed one test to war

Look like a whale hero

(Shahnameh, 1374: 178)

Sohrab does not leave Gardafarid's rivalry unanswered and comes to the fore. Gardafardi, who has passed away and goes to Sohrabi's war out of love for his homeland, who has frightened the Iranians, answers Sohrab Rajazkhani Gerdafarid's reading in this way. :

Chushehrab Shiravgen give him

Laugh and bite your lip

That's what Kamed said about the grave 
To the snare of God sword and force

Gerdafarid loses the battle with all his courage and bravery, but uses feminine tactics and decides Reveal his feminine identity, in order to dissuade Sohrab from continuing the battle. This wise decision of his is to be a worker, to recreate his creation and to surprise Sohrab.

Surprised, he told the IRGC about Iran

Such a girl comes to the place

(Same).

Gerdafarid then tells Sohrab that if he leaves him, he will hand over the White Fortress to him, but until he reaches the fort, he throws himself inside the fort and the guards immediately close the doors. Gerdafarid saves himself with wisdom and prudence. Every time he goes to the top of the fort and looks at Sohrab, he realizes that Sohrab has fallen in love with him.

Chou saw Sohrab behind the saddle

This is what Kai Shah, the Turk of China, said

Why did you go back now?

He did not hesitate to come

Laugh and say sorry

That the Turks do not find pilgrims in pairs

That's how it was, and one day you weren't there

Don't be sad about yourself

(Same).

In the end, his arrogance takes a hint of advice and advises Sohrab to return to Turan and save his young life from death.

By force and arm and that shoulder vial

You don't have any of Hamal's heroes

But when it comes to the king

That brought the rotation of the IRGC

Shahshah and Rostam are moving

You don't have to slander

Don't let anyone live in your army

I don't know what will happen to you

I'm sorry, Kane, it's so hard

Some of the leopards must be hiding

It is better for you to obey

Make a face for Turan

Don't be so safe with your arm

Eat your ignorant Zephlavi

(Same: 180).

Since one of the functions of reading aloud is to give advice to the opponent and to warn him against continuing the war, this part of the conversation shows the wisdom and prudence of a warrior woman who, while being proud in defense of the homeland, is the essence of chastity. She has preserved herself and has not surrendered her body and soul to her opponent, but as we will see, in the Bahman and Homay war, the opposite is true. 
"Homay Del Afrooz is descended from the king's family and the daughter of the king of Egypt, Harith, who according to the story and at that time is from the countries under the command of the Shah of Iran. The character of the maiden is very beautiful, but she is very militant and warrior, and she is not able to go around with him in all the lands of Egypt. Defeat hand to hand in battle "(Siraj, 2013: 5)

The hero in front of him is Bahman, the son of Esfandiar, who learned the etiquette of warfare from Rostam, and for this reason he has similarities with Sohrab. His play and hand-to-hand battles go unnoticed and he is ultimately amazed and finally decides to go hand in hand with Homay.

Iranshah This Abi Al-Khair has given very detailed descriptions of the arrogance of these two, which we will now briefly discuss:

At the beginning of Bahman's confrontation, in order to humiliate and weaken Homay's morale, he tells him that I have saved your father from being killed.

When I went to my father, he said it was too late

If I throw you, I'll throw you down

It doesn't hurt, it doesn't hurt

Religion and religion

(Ibn Abi Al-Khair, 1991: 125).

Homay also gives a tooth-breaking answer to Bahman:

He replied that you were staring

Don't eat unripe fruit

You didn't see me on the day of the battle

Do you know where you came from?

(Same).

In response, Bahman says:

He said at first that I had seen Bahman

I like your war

But the lion came and the deer arrived

Nobody saw a deer in Shiraz

(Same).

After these boastings, Bahman tells him that he must fight without the intervention of the army, and Homay says in response to Bahman:

Homay Del Afrooz said, "Ride."

Don't get me wrong

When my injury is over

My spearhead reaches Janet

You know, you are a test warrior

You don't have a lion in your foot to fight

(Ibid: 129).

Homay is defeated by Bahman with all his courage and boldness and falls under the foot of Bahman due to the slipping of his horse's foot. It is better to hear the end of the battle from Bahman and his beautiful arrogance. 
Homay returned from a different land

At that time, Bahman died

He put his spear on his head

He said at first that he was a bad villain

You sang to John twice

What did I do?

It's like leaving you behind

Take your spear from the ground

You don't have a battalion

Why aren't you in the house?

At first, Kai Namvar Shahriyar said

I'm sorry, Kamkar

(Ibid: 131).

Despite the beautiful payment of Bahman and Homay boastings, the nature of these boastings is completely different from Sohrab and Gerdafarid boastings, some of which we will mention now:

1- Sohrab does not know that his opponent is a woman, but Bahman already knows that he is fighting a woman

2- Gerdafarid fights with the intention of defending the homeland, but Homay fights with the intention of finding a husband, and in this respect, the value of this battle is much lower than the war between Sohrab and Gerdafarid.

\section{Conclusion}

After examining the examples of arrogance in the two national epics of Shahnameh and Bahmannameh, we find that arrogance is an integral part of epic works and in these arrogance, beliefs, beliefs and values of a nation are reflected by the existence of arrogance in Epic works are due to the fact that in fact, the battle in the two realms of speech and physical power go hand in hand and are considered complementary and supportive. Therefore, in addition to physical strength equipped with the art of expression, the heroes must be present in response and language In this way, they can strengthen the morale of the IRGC and break the psychological security of the opposing forces. The use of this tool in two works (Shahnameh, Bahmannameh) are different from each other, which can be concluded as follows:

1- In Shahnameh, arrogance is mostly done directly and face to face, but in Bahman, most of the arrogance is seen as an indirect letter and expression.

2- Ferdowsi has observed politeness even when the arrogant take the aspect of humiliation and ridicule, but in Bahmannameh, the arrogant go through these steps and even take the aspect of insult and insult.

3- Arrogance is stronger in Shahnameh and is used with an effective tone, while in Bahmannameh, arrogance has a weak and unstable language.

4- In Shahnameh, the motivation of the heroes in arrogance is more national and patriotic, while in Bahmannameh, they have taken on a more personal aspect and settling accounts. 
5- In the women's boasting section, Gerd Afarid enters the field anonymously and boasts like men and fights to defend Iran, but in Bahmannameh, Homay Del Afrooz's letter states that she is a woman from the very beginning and entered to find her husband. The arena has been

For this reason, the above features have diminished the value of Bahmannameh's position and reduced it to imitation, but because it contains unspoken words about Bahman's life and the history of the Zal family, it has value and credibility.

\section{References}

1-Ibn Abi Al-Khair, Iran Shah, (1991), Bahmannameh by Rahim Afifi, Tehran, Scientific and Cultural Publications.

2-Ibn Manzur, Muhammad ibn Makram, (2000), The Language of the Arabs. C 18, Beirut, Dar Sadr.

3-Jafari, Hamid, (2009), Evaluation of Bahmannameh with Shahnameh, Iranian Studies Magazine, No. 15.

4-Dad, Sima, (1991), Dictionary of Literary Terms, Tehran, Qatreh.

5-Dehkhoda, Ali Akbar, (), Dictionary, Dictionary Institute, University of Tehran

6-Siraj, Shahin, (2013), The face and personality of women warriors in national epics, the Shahnameh and Iran website.

7-Cerami, Ghadmali, (2004), From the color of the flower of the history of thorns, Tehran, scientific and cultural publications.

8-Safa, Zabihullah, (1984), Epic Poetry in Iran, Tehran, Amir Kabir.

9-Ferdowsi, Abolghasem, (1374), Shahnameh based on Moscow edition, Tehran, Qatreh Publishing.

10-Fallah, Gholam Ali, (2006), Pride in Shahnameh, Journal of the Faculty of Literature and Humanities, Tarbiat Moallem University of Tehran, No. 54 and 55.

11-Mostafavi, Hassan, (2006), Research in Quranic Words, Qom, Allameh Mostafavi Publishing Center.

12-Moin, Mohammad, (1992), Persian Culture, Tehran, Amir Kabir.

13-Mir Sadeghi, Jamal, (1997), Elements of Story, Tehran, Sokhan Publications. 